УДК 378.016:811.11

DOI 10.11603/me.2414-5998.2020.1.11000

N. I. Yelahina

ORCID https://orcid.org/0000-0002-5423-8327

ResearcherID Q-4615-2016

N. O. Fedchyshyn

ORCID https://orcid.org/0000-0002-0909-4424

ResearcherID Q-5422-2016

Scopus Author ID 57202833382

\author{
I. Horbachevsky Ternopil National Medical University
}

\title{
GAMES AS A MEANS OF LEARNING A FOREIGN LANGUAGE BY MEDICAL STUDENTS
}

\author{
Н. І. Єлагіна, Н. О. Федчишин \\ Тернопільський національний медичний університет імені І. Я. Горбачевського МОЗ Украӥни \\ ІГРОВА МОДЕЛЬ ЯК ЗАСІБ ВИВЧЕННЯ ІНОЗЕМНОЇ МОВИ
СТУДЕНТАМИ-МЕДИКАМИ
}

Abstract. The article analyzes the role of the educational game as a means of organizing the speech activity of medical students in English. The authors of the article emphasize the need to use active teaching methods in the educational process while learning English. It has been established that games in English classes can be divided into the following categories: games aimed at mastering new vocabulary; games aimed at grammatical material consolidation; communication games aimed at developing students' monologs and dialogs. Methods, goals and tasks for forming a communicative model are highlighted. Examples of interaction between a teacher and a student are analyzed. It is noted that the conduct of professional games has a multi-faceted approach and is carried out according to a certain model. Systematic and purposeful use of games as a method of teaching English to medical students contributes to the effective learning in the educational process.

Key words: English language; educational game; educational process; medical students; professional activity.

\begin{abstract}
Анотація. У статті висвітлено роль навчальної гри як засобу організації мовленнєвої діяльності студентів-медиків англійською мовою. Автор статті підкреслює необхідність використання у навчальному процесі з англійської мови активних методів навчання. Встановлено, що ігри на заняттях з англійської мови можна поділити на такі категорії: ігри, спрямовані на засвоєння лексичних одиниць; ігри, спрямовані на закріплення граматичного матеріалу; комунікативні ігри, які спрямовані на розвиток монологічного та діалогічного мовлення студентів. Висвітлені методи, цілі і завдання для формування комунікативної моделі. Проаналізовані приклади взаємодії викладача і студента. Наголошується, що проведення професійних ігор має різнобічний характер та проводиться за певною моделлю. Систематичне та цілеспрямоване використання ігор як методу навчання англійської мови для студентів-медиків сприяє ефективному засвоєнню навчального процесу.
\end{abstract}

Ключові слова: англійська мова; навчальна гра; навчальний процес; студенти-медики; професійна діяльність.

Introduction. The importance and usefulness of games in foreign language learning has become more and more vital in the current world. Basic lesson activities such as written exercises and chapter translations tend to be tedious after a while. In order for the teacher to invent motivating and challenging language learning experiences for students, games can be used to link the spare time of the students to learning. By using games in foreign language learning students can learn grammar, vocabulary and oral skills unconsciously in a supervised situation.
The use of games in the educational process is constantly discussed in a variety of manuals on the theory and practice of teaching a foreign language, since games arouse the interest of teachers, giving them the opportunity to improve the learning process, increase the motivation of students and contribute to their abreaction. Speaking about the role of the game for the purpose of education, it should be noted that its learning opportunities have been known for a long time. Many outstanding scientists have paid attention to the effectiveness of the use of games in

(C) N. I. Yelahina, N. O. Fedchyshyn 
the educational process. Various aspects of the use of games in the educational process were studied by scientists (N. Fedchyshyn, I. Kulish, E. Passov, M. Skatkin, H. Selevko, N. Tkacheva, O. Tur, $\mathrm{N}$. Yelahina, etc.). However, the use of games aimed at deepening the cognitive activity of medical students in English classes was not the subject of detailed scientific research.

The aim - to analyze the possibilities of educational games in English classes at a non-linguistic (medical) university.

Theoretical framework. In the methodology of teaching a foreign language, there are various ways to optimize educational activities, including games. The meaning of the word game is periodically described in the methodological manuals. It arouses the interest of foreign language teachers as it can be used to motivate students as well as to train and control their knowledge and skills. Game-based learning can be the most effective way to teach students basic concepts that were previously learned through repetition and written exercises [5, 8].

There are cases when tasks and learning tools that are offered for students, do not sufficiently arouse the interest of students and do not get them involved in the educational process. The solution to the problem is to use an educational game that activates the student's cognitive activity and increases interest in what is being studied in lessons [9].

Interaction and communication is the key to success in the learning process. Games can help set the stage for such meaningful interaction. One of the critical aspects of teaching a foreign language is learning the spoken language, that creates the conditions for the disclosure of the communicative function of language, which allows to bring the learning experiences to the real training that increases motivation for the study of the subject [9].

For the purpose of our article we have taken the word 'game' to mean an activity which is engaging, often challenging, and an activity in which the learners play and usually interact with others [1]. Language learning is hard work. One must make an effort to understand, to repeat accurately, to adapt and to use newly understood language in conversation and in written composition. Effort is required at every moment and must be maintained over a long period of time. Games help and encourage many learners to sustain their interest and work.

Games also help the teacher to create contexts in which the language is useful and meaningful. The learners want to take part, and in order to do so must understand what others are saying or have written, and they must speak or write in order to express their own point of view or give information. Games provide one way of helping the learners to experience language rather than merely study it [5].

Many games cause as much use of particular language items as more conventional drill exercises; some games do not. What matters, however, is the quality of practice. The contribution of drill exercises lies in the concentration on a language form and its frequent occurrence during a limited period of time. Many games similarly provide repeated occurrence and use of a particular language form. By making language convey information and opinion, games provide the key features of 'drill' with the added opportunity to sense the working of language as living communication. Games involve the emotions, and the meaning of the language is thus more vividly experienced. It is, for this reason, probably better absorbed than learning based on mechanical drills.

Of the four types of grouping, individual, pair, and group work are of especial value in ensuring that each and every learner has optimum opportunity for oral practice in using language, going beyond what is possible in class work.

Pair work is easy and fast to organise. It provides opportunities for intensive listening and speaking practice. Pair work is usually better than group work if there are discipline problems. An essential feature of the exercises for pair work is that they, unlike teacherup-front style of exercises, can not be focused on the "average" student. Such exercises should be absolutely feasible for all participants in the training. If this requirement is not implemented, then low-performing students are discreetly excluded from mass training or make many mistakes. At the same time, these exercises should not be too easy, that is, focused on the lowperforming students, because in this case they will not ensure the progress of the high-achieving students [4].

Some games require four to six players; in these cases group work is essential. If there is to be competition between groups, they should be of mixed ability. If there is to be no such challenge, the teacher might choose groups according to ability: this is very much a personal choice. Many teachers consider it advisable to have a group leader. However, it is our experience that groups can operate perfectly well without a group leader. The leader would normally be one of the more able learners. However, there is much to be said for encouraging a reticent learner by giving the responsibility to him or her. The leader's role is to 
ensure that the game is properly organised, and to act as an intermediary between learners and teacher.

Group work, one of the most important areas for medical students to develop their communicative skills, is gradually being used to teach English as a foreign language. Group work refers to any classroom activity in which the entire group of students is divided into pairs or large groups. Studies have shown that the group work method is useful when learning foreign languages, as it helps students to participate in various types of interaction. It also supports a more favorable psychological and creative atmosphere in the classroom. So, A. Brown noted that "group work provides an activity in which people help each other; it is a way to help groups as well as helping individuals; and this method can allow individuals and groups to influence and change personal, group, organizational, and social issues" [6].

In order to develop future doctors' perceptual and communicative skills in English, in addition to educational games, methods of active social and psychological training were used, namely, group discussions. In group work, special attention is paid to the role of students' interaction, the use of adequate verbal and nonverbal means of communication, strategies for behavior in conflict situations, techniques for solving problem situations, and so on. The point of view expressed by the student during the discussion could either reflect his own opinion or be based on the opinions of other people. A successful discussion had a great educational value, because it teaches a deeper understanding of the problem, the ability to defend your position and take into account the opinions and points of view of other people [3].

Despite the fact that the language capabilities of groups and individual students are not the same and only the teacher knows their actual level, it is necessary to creatively approach the proposed exercises and, if necessary, make appropriate adjustments.

The proposed forms of work should be a means of intensive completion of the most important portions of the language material included in the plan. The vast majority of exercises has a grammatical orientation. They are based on speech patterns. A lot of attention is also paid to the so-called linking words, which play an important role in making up sentences. Pair work exercises will also help to consolidate vocabulary and develop intonation skills. Along with this, some of the exercises (about $30 \%$ ) have a slightly different purpose. They are a means of developing dialogical and monological speech and are offered as a form of preparation for an independent statement on a topic.

As a rule, working in a group, students have improved communication skills, both team spirit and the characteristics of the leader of some individuals. This creates conditions for individual self-expression within the group, the ability to work in a team, and develops a competitive spirit that helps motivate students to expand their knowledge in improving communication and verbal consolidation of their positions. This method teaches the student to actively search for an answer independently, which is one of the main tasks of the Bologna process.

The teacher's role, once the groups or pairs are in action, is to go from group to group listening in, contributing and, if necessary, correcting. If you have not organised group work before, then it is advisable to work slowly towards it. First of all, make the learners familiar with work in pairs. Add to this games in which rows of learners (if that is how they are seated) play against you or between themselves. Finally, after perhaps several weeks, ask the rows of learners to group themselves together to play a game between themselves [2].

To minimise difficulties, it is essential that the learners are very familiar with the games they are asked to play. (It is helpful if they are familiar with the game in their own language.) Once the learners are familiar with group work, new games are normally introduced in the following way:

1) explanation by the teacher to the class;

2) demonstration of parts of the game by the teacher and one or two learners;

3) trial by a group in front of the class;

4) any key language and/or instructions written on the board;

5) first 'try out' of the game, by groups;

6) key language, etc., removed from the board;

7) the game continues.

Being aware of the essential character of a type of game and the way in which it engages the learner can be helpful in the adaptation of games or the creation of new games.

Educational games are quite an important tool and play an important cultural role in the life of students. It is proved that they can be more motivating, complex and interesting than formal methods offered in the educational process. Using it as a means of learning, many outstanding teachers rightly noted the great potential of the educational game. So, with the help of the game, pronunciation is well practiced, lexical and grammatical material is activated, listening and 
speaking skills are developed. Didactic games help to make the process of learning a foreign language interesting and exciting. A sense of equality and an atmosphere of enthusiasm allow students to overcome the inconvenience, stiffness, remove the language barrier, and fatigue. The educational game has a goal and tasks. Game planning should begin with determining the training task that should be solved in this game, and then you should build the game itself, determine the game rules [7].

A continuous educational game, unlike traditional educational games, combines the entire educational process with a single game's plot for all educational and communicative activities. The only one game's plot that is developed in a continuous educational game from lesson to lesson, the only characters in this game create an imaginary life continuum in which students master both professional English and their profession, constantly playing it in conditions that mimic or simulate a professional medical environment. At the same time, it is very important that students independently create this environment in the process of independent development of the game's plot.

The medical educational game provides many opportunities for medical students to realize their creative potential. Students have opportunities to express their views, to express themselves creatively in the educational process. This type of work, modeling the real professional activity of doctors, provides practical implementation of professionally-oriented English-language communicative competence, since in their educational activities, students imitate what they will have to do in real English-language professional communication.

The problem character in a continuous educational game is associated with the solution of a certain professionally-oriented task, which implies several possible ways to solve it, so the use of certain problem tasks, solving of situational problems, creating projects, organizing thematic conversations during the lesson should precede the game and prepare its implementation in the educational process.

We conducted a medical game-based learning activities that covered 30 to 40 percent of the lesson time. It was the main means of developing Englishlanguage professional communication skills, but not the only one in our educational process.

We offer an example of a medical educational game for the 2nd year students in the specialty "Medicine" played in the Foreign (English) Language lesson. The aim of the game is to develop students' skills for analyzing the patient's condition, determining diagnostic methods, and developing skills for treating and preventing the patient's condition. Roles are distributed in the following types of interaction: "doctor-patient", "doctor-relative of the patient", "nurse-doctor", "doctor-doctor". This distribution of roles helps you find the right solution, build your own line of behavior, apply interpersonal communication skills, demonstrate practical skills learned in the previous lessons, integrate the knowledge gained in other lessons and direct them to solving a problem situation. Simulation game "Patient care":

1. Brainstorm possible complaints, family history that a patient could have.

2. Divide the class into groups of 3-4. Groups No. 1 and 2 are medical personal and groups No. 3 and 4 are patients, relatives.

3. Each patient has problems and they have to imagine as many problems as they can (the more they have, the better it is): e.g. examine the patient and determine basic symptoms of the disease, if the patient refuses to be examined and further treated, discuss the prescribed treatment with the relatives of the patient.

4. Give them 3 minutes to try to solve the problems (which is obviously not long enough).

5. Ask students to make a report on the results of patient examination at council of physicians (give them 10-15 minutes). Collect the letters and exchange them.

6 . Tell them they are council of physicians and they have to write back and to give these people some advice.

7. Collect the letters and redistribute them. Analyze the results.

As a result of the educational game, we can conclude that it is multifunctional, which develops the ability to think independently and make decisions, trains and strengthens professional knowledge, as well as forms language, intercultural and communicative competence. During the game, students have a constant exchange of information, not just consolidation of knowledge of oral English communication, but a real exchange of professional knowledge, offering solutions to certain problems, optimal treatment options, the latest medications, and so on. Usually, the professional educational game is the final stage of training, which is preceded by all the other work on the formation of English-language professional communication skills.

There were used not dissected tasks in the professional educational games, but educational ones presented in the form of specific situations of professional communication. Such situations could contain 
conflicting, unnecessary or incorrect data, requiring to find additional information, and so on. During the game, the student had to analyze the situation in English, identify the problem, formulate the tasks, find solutions, prove the correctness of the decision, perform the appropriate practical actions, and evaluate their effectiveness. In other words, a communicative and cognitive approach to learning English was implemented here. This is the algorithm used by a doctor in real English-language professional communication.

Conclusions and Prospects for Research. The peculiarity of using a professional educational game in the process of learning a foreign language is its communicative orientation. Communication is the main way to attract game participants to take part in

\section{List of literature}

1. Єлагіна Н. І. Навчальні ігри як ефективний засіб вивчення іноземної мови студентами-медиками / Н. І. Єлагіна, Г. І. Кліщ, Н. О. Федчишин // Дослідження та впровадження в начальний процес сучасних моделей викладання іноземної мови за фахом : зб. матеріалів III Всеукр. наук.практ. інтернет-конф. 3 питань методики викладання іноземної мови, 15 травня 2017 р. - Одеса, 2017. - С. 63-66. http://lingvo.onu.edu.ua/wp-content/uploads/2017/05/\%D0\% A1\%D0\%91\%D0\%9E\%D0\%A0\%D0\%9D\%D0\%98\%D0 \%9A-2017-3.pdf.

2. Єлагіна Н. І. Рольова гра як аспект мотивації у викладанні іноземних мов студентам-медикам / Н. І. Єлагіна // Наукові записки Національного університету «Острозька академія». Серія «Психологія і педагогіка». - Острог, 2014. - Вип. 26. - С. 66-69.

3. Миролюбов А. А. Современные педагогические технологии / А. А. Миролюбов // Методика обучения иностранным языкам: традиции и современность / под ред. А. А. Миролюбова. - Обнинск : Титул, 2010. С. 346-348.

\section{References}

1. Yelahina, N., Fedchyshyn, N., \& Klishch, H. (2017). Navchalni ihry yak efektyvnyi zasib vyvchennia inozemnoi movy studentamy-medykamy [Educational games as an effective means of learning a foreign language by medical students]. Doslidzhennia ta vprovadzhennia $v$ nachalnyi protses suchasnykh modelei vykladannia inozemnoi movy za fakhom: Zbirnyk Vseukrainskoi naukovo-praktychnoi internet-konferentsii - Research and Implementation of Modern Models of Teaching a Professional Foreign Language in the Educational Process: Collection of the All-Ukrainian Scientific and Practical Internet Conference. Odesa [in Ukrainian].

2. Yelahina, N. (2014). Rolova hra yak aspekt motyvatsii u vykladanni inozemnykh mov studentam-medykam cognitive activity and at the same time it is the way of creating and solving problem situations. It helps students to make individual and group decisions and to achieve the goals of each specific game. Students combine their efforts, experience, and creative potential for joint actions aimed at effective treatment of the "patient". They experience complete creative freedom, psychological freedom that allows them to express their thoughts in a foreign language without fear of being misjudged by the teacher. Educational games are an effective means of preparing future doctors to solve problem situations in their professional performance, which determines the reasonability of introducing these games into the educational process of a medical university.

4. Пометун О. Сучасний урок. Інтерактивні технології навчання : наук.-метод. посіб. / О. І. Пометун, Л. В. Пироженко ; за ред. О. І. Пометун. - К. : Видавництво: A.C.K., 2004. - 192 с.

5. Федчишин Н. О. Використання дидактичної гри при вивченні німецької мови в умовах університету / Н. О. Федчишин // Наукові записки Національного університету «Острозька академія». Серія «Психологія і педагогіка».-Острог : Видавництво Національного університету «Острозька академія», 2014. - Вип. 26. - С. 132-135.

6. Brown A. Group work / Alan Brown. - 3rd ed. - London : Heinemann, 1992. - 229 p.

7. Hedge P. Teaching and learning in the language classroom / P. Hedge. - Oxford : Oxford University Press, 2000. - 447 p.

8. Thiagarajan S. Teamwork and team play: Games and activities for building and training teams / S. Thiagarajan. - San Francisco : Jossey-Bass, 1999. - 176 p.

9. Wright A. Games for language learning (3rd ed.) / A. Wright, D. Betteridge, M. Buckby. - New York : Cambridge University Press, 2005. - 191 p.

[Role-playing as an aspect of motivation in teaching foreign languages to medical students]. Naukovi zapysky Natsionalnoho universytetu “Ostrozka akademiia”. Seriia "Psykholohiia i pedahohika”, 26, 66-69 [in Ukrainian].

3. Murolyubov, M. (2010). Sovremennye pedagogicheskie tehnologii [Modern pedagogical technologies]. Metodika obucheniya inostrannym yazykam: traditsii i sovremennost. Mirolyubov, A.A. (Ed.). Obninsk: Tytul [in Russian].

4. Pometun, O., \& Pyrozhenko, L. (2004). Suchasnyi urok. Interaktyvni tekhnolohii navchannia [Modern lesson. Interactive learning technologies : manual]. Pometun, O.I. (Ed.). Kyiv: Vydavnytstvo: A.S.K [in Ukrainian].

5. Fedchyshyn, N.O. (2014). Vykorystannia dydaktychnoi hry pry vyvchenni nimetskoi movy v umovakh universytetu 
[Educational games for learning German at the universities]. Naukovi zapysky Natsionalnoho universytetu "Ostrozka akademiia”. Seriia "Psykholohiia i pedahohika”. Ostroh: Vydavnytstvo Natsionalnoho universytetu "Ostrozka akademiia" [in Ukrainian].

6. Brown, A. (1992). Group work. London: Heinemann. 3rd ed.
7. Hedge, P. (2000). Teaching and learning in the language classroom. Oxford: Oxford University Press.

8. Thiagarajan, S. (1999). Teamwork and team play: Games and activities for building and training teams. San Francisco: Jossey-Bass.

9. Wright, A., Betteridge, D., \& Buckby, M. (2005). Games for language learning. 3rd ed. New York: Cambridge University Press.

E-mail address for correspondence: yelaginani@tdmu.edu.ua 